\title{
PENUNDAAN PEMBAYARAN UPAH PEKERJA DI PABRIK SANDAL UD. NUSANTARA DESA PASANGGAR KECAMATAN PEGANTENAN KABUPATEN PAMEKASAN PERSPEKTIF HUKUM ISLAM
}

\author{
Zainollah \\ Fakultas Syariah IAIN Madura Jl. Raya Panglegur Km. 4 Pamekasan, \\ zainollah@gmail.com \\ Agung Fakhruzy \\ Fakultas Syariah IAIN Madura Jl. Raya Panglegur Km. 4 Pamekasan, \\ agung.fakhruzy@gmail.com
}

\begin{abstract}
Abstrak:
Ijarah merupakan akad sewa yang dapat digunakan seseorang untuk bisa menggunakan jasa orang lain atau manfaat atas suatu barang dalam menyelesaikan suatu pekerjaan yang diperbolehkan dalam Islam. Dengan adanya akad tersebut, penyewa memiliki kewajiban untuk membayar upah sebagai salah satu kewajibannya kepada orang yang disewa jasanya. Islam menganjurkan untuk mempercepat pembayaran upah dan melarang untuk menunda-nundanya. Praktik penundaan upah terjadi di UD. Nusantara Pasanggar Pegantenan Pamekasan. Fenomena ini menjadi penyebab utama atas kekesalan para pekerja dan mengurangi keihklasan pekerja dalam melaksanakan tugas. Penundaan pembayaran upah yang terjadi di UD. Nusantara merupakan perbuatan yang bertentangan dengan prinsip perburuhan dalam hukum Islam yang lebih mengutamakan pembayaran upah bagi pekerja secara langsung setelah pekerjaannya usai. (IJarah is a lease that can be used by someone to use the services of others or the benefits of an item when completing a work that is permitted in Islam. With the existence of the contract, the tenant is obliged to pay the wage as one of his obligations to the person hired for his services. Islam advocates speeding up the payment and prohibiting them from postponing it. The practice of wage delays takes place at UD. Nusantara Pasanggar Pegantenan Pamekasan. This phenomenon is the main cause of employee resentment and reduces the exclusion of employees in the performance of their duties. Delays in the payment of wages that occur at UD. Archipel is an act that violates the labor
\end{abstract}


principle in Islamic law, which gives priority to the payment of wages for employees immediately after work is over.)

Kata Kunci:

Penundaan pembayaran, Upah pekerja, Hukum Islam

\section{Pendahuluan}

Hukum ketenagakerjaan di Indonesia diatur secara khusus dalam Undang-undang Nomor 13 Tahun 2003 tentang Ketenagakerjaan (selanjutnya disingkat UU Ketenagakerjaan). Dalam Pasal 1 ayat (1) UU Ketengakerjaan disebutkan bahwa yang dimaksud dengan ketenagakerjaan adalah segala hal yang berkaitan dengan tenaga kerja pada waktu sebelum, selama dan sesudah masa kerja. ${ }^{1}$ Adapun tenaga kerja, disebutkan pada Pasal 1 ayat (2) UU Ketenagakerjaan bahwa tenaga kerja adalah setiap orang yang mampu melakukan pekerjaan guna menghasilkan barang dan/atau jasa baik untuk memenuhi kebutuhan sendiri maupun untuk masyarakat. ${ }^{2}$

Tenaga kerja jika dikaitkan dengan peranan dan pendapatannya dapat digolongkan atas pengusaha dan karyawan atau manager dengan buruh. ${ }^{3}$ Dua komponen tersebut memiliki hubungan yang disebut degan hubungan kerja. Hubungan kerja adalah suatu hubungan antara pekerja dan pengusaha, yang terjadi setelah diadakan perjanjian kerja, dan pekerja menyatakan kesanggupannya untuk bekerja pada pengusaha dangan menerima upah, dan pengusaha menyatakan kesanggupannya untuk mempekerjakan buruh dengan membayar upah. Jadi, dalam hal ini ada hubungan kerja antara atasan dan bawahan (subordinasi). ${ }^{4}$

Menurut Pasal 1 angka 15 UU Ketenagakerjaan, hubungan kerja adalah hubungan antara pengusaha dengan pekerja/buruh berdasarkan perjanjian kerja yang mempunyai unsur pekerjaan, upah, dan pemerintah. Perjanjian kerja adalah perjanjian antara pekerja/buruh dengan pengusaha atau pemberi kerja yang memuat syarat-syarat kerja, hak, dan kewajiban para pihak. ${ }^{5}$

${ }^{1}$ Undang-Undang Nomor 13 Tahun 2003 tentang Ketenagakerjaan.

${ }^{2}$ Ibid.

${ }^{3}$ Malayu S. P. Hasibuan, Manajemen Sumber Daya Manusia (Jakarta: PT Bumi Aksara, 2015),. 117.

${ }^{4}$ Zaeni Asyhadie, Hukum Perusahaan Dan Kepailitan (PT Gelora aksara pratama, 2012),. 24

${ }^{5}$ Ibid,. 24. 
Dalam membahas tenaga kerja, tidak dapat dipungkiri adanya pembahasan tentang upah. Hal ini dikarenakan upah merupakan tujuan utama yang ingin didapat oleh orang yang bekerja guna memenuhi segala kebutuhannya. Disebutkan dalam UU Ketenagakerjaan, tepatnya pasal 1 ayat (30) menyatakan bahwa upah adalah hak pekerja/buruh yang diterima dan dinyatakan dalam bentuk uang sebagai imbalan dari pengusaha atau pemberi kerja kepada pekerja/buruh yang ditetapkan dan dibayarkan menurut suatu perjanjian kerja, kesepakatan, atau peraturan perundang undangan, termasuk tunjangan bagi pekerja/buruh dan keluarganya atas suatu pekerjaan dan/atau jasa yang telah atau akan dilakukan. 6

Upah itu sendiri mengambil peranan yang sangat penting dalam sebuah perusahaan karena upah menjadi salah satu faktor pendorong dalam kinerja karyawan. Dimana kinerja yang bagus dapat menunjang prduktivitas perusahaan. Agar upah dapat diterima sesuai dengan hak karyawan dan aktivitas perusahaan dapat berjalan dengan lancar, maka perusahaan membutuhkan sistem atau prosedur yang baik. Hal ini menunjukkan bahwa upah merupakan salah satu komponen terbesar dari suatu pendapatan seseorang sehingga bisa dikatakan berkembang. Upah adalah salah satu indikator `yang dapat mencerminkan kesejahteraan bagi masyarakat.

Dalam Islam, upah - mengupah itu merupakan transaksi yang dikenal dengan sebutan Ijarah, yakni transaksi yang memperjualbelikan manfaat suatu harta benda, sedangkan kepemilikan pokok benda itu tetap pada pemiliknya. ${ }^{7}$ Ijarah itu sendiri merupakan transaksi yang diperbolehkan dalam hukum Islam, hal itu sebagaimana disebutkan dalam al-Quran surat al-Thalaq ayat 6, yaitu:

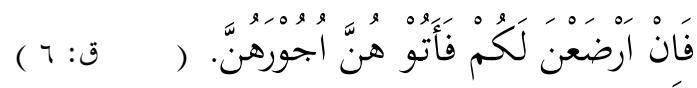

"Jika mereka telah menyusukan (anak-anak)mu untukmu, maka berikanlah kepada mereka upahnya". (Al-Thalaq: 6). ${ }^{8}$

Ayat di atas menjelaskan tentang seorang ibu yang menyusukan anaknya kepada orang lain yang mana Allah SWT. memerintahkan agar orang yang menyusukan diberikan upah atas apa yang telah dilakukannya. Oleh karena itu ayat ini menjadi salah satu dalil yang

\footnotetext{
${ }^{6}$ Undang-Undang Nomor 13 Tahun 2003 tentang Ketenagakerjaan.

${ }^{7}$ Ahmad Sarwat, Seri Fiqih Kehidupan (7) : Muamalat, (Jakarta: DU Publishing, t. th. ),. 77-78.

${ }^{8}$ Departemen Agama ,Al-Qur'an Dan Terjemahannya (Bandung: CV. Penerbit JArt, 2005),. 560.
} 
dapat digunakan sebagai dasar atas kebolehan transaksi ijarah atau upah-mengupah.

Dalam melakukan akad ijarah, terdapat beberapa rukun dan syarat tertentu yang harus dipenuhi agar akad yang dilakukan benarbenar sah menurut pandangan hukum Islam. Hal tersebut dikarenakan jika suatu akad dilakukan dengan tanpa memenuhi rukun dan syaratnya, maka akad tersebut tergolong ke dalam transaksi yang bathil dan dilarang dalam pandangan hukum Islam. Sebagaimana dinyatakan dalam kompilasi Hukum Ekonomi Syariah Pasal 28 ayat (3) yang menentukan tentang akad batal, bahwa akad batal adalah akad yang kurang rukun dan atau syarat-syaratnya. ${ }^{9}$

Selain itu dalam melakukan transaksi ijarah, setiap pekerja haruslah diberikan upahnya secara adil dan tidak menunda-nunda tanpa ada kejelasan dari atasannya. Hal ini sudah dijelaskan oleh Rasulullah SAW. Bahwa:

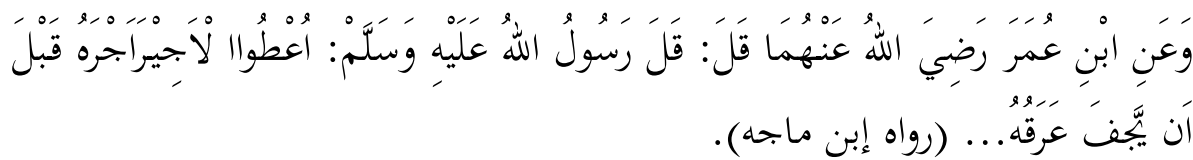

"Dari Ibnu Umar RA. Ia berkata "Rasullah Saw. Bersabda:" Berilah kepada pekerja upahnya sebelum keringatnya kering"( HR. Ibnu Majah). ${ }^{10}$

Hadits di atas menejelaskan tentang perintah disegerakannya pemberian upah kepada setiap pekerja. Di mana sistem pembayaran mengembangkan struktur pembayaran dan sistem yang layak, adil dan transparan. Pembayaran untuk kontribusi mengkaitkan imbalan dengan usaha, hasil, kecakapan dan keterampilan. Imbalan non finansial memberi imbalan non finansial kepada karyawan. ${ }^{11}$

Di Desa Pasanggar ada salah satu pabrik sandal UD. Nusantara, yang menggunakan beberapa orang untuk disewa jasanya dalam melakukan produksi sebuah sandal. Dalam praktiknya, karyawan dengan atasan yang ada di pabrik tersebut membuat kontrak secara lisan terlebih dahulu mengenai imbalan/upah. Imbalan/upah tersebut tidak diberikan perhari, perminggu ataupun perbulan melainkan imbalan/upah bisa diminta kapan saja. Hal itu

\footnotetext{
${ }^{9}$ Kompilasi Hukum Ekonomi Syariah, 18.

${ }^{10}$ Ibnu Majah, Sunan Ibnu Majah, dalam Ensiklopedia Hadits 4 Sunan Ibnu Majah, ed. Muhammad Ghazali, et. Al. (Jakarta: Almahira, 2013),. 441.

11 Sedarmayanti,Manajemen Sumber Daya Manusia, Reformasi Birokrasi, Dan Manajemen Negeri Sipil (Bandung:PT Refika Aditama ,2007),. 19.
} 
dikarenakan dalam melakukan kontrak tersebut menggunakan sistem borongan, yang setiap hasil produksi karyawan dapat diuangkan sesuai dengan jumlah dan model sandalnya.

Berkaitan dengan besaran upah di UD. Nusantara yang diberikan kepada karyawannya, memiliki banyak variasi jumlah upah yang sudah ditentukan di awal kontrak antara pekerja dengan pemilik pabrik. Hal tersebut ditentukan bedasarkan model sandal, tebal sandal, dan ukuran sandal yang dihitung per-pasangnya.

Adapun yang menjadi permasalahan adalah ketika karyawan hendak meminta upah atas pekerjaan yang telah dilakukannya, terkadang atasan masih menunda upah yang diminta oleh karyawan yang membutuhkannya. Hal tersebut sangatlah tidak adil yang pada dasarnya bertentangan dengan kontrak yang ada, sehingga membuat pekerja merasa jengkel dan sakit hati karena apa yang diharapkannya tidak tercapai, yakni tidak dapat menikati upah yang pada dasarnya hal itu sudah menjadi hak pekerja yang sudah menyelesaikan pekerjaannya. ${ }^{12}$

\section{Metode Penelitian}

Penelitian ini menggunakan pendekatan kualitatif yang mengkaji tentang bagaimana seseorang mengalami suatu kejadian atau fenomena. Dalam jenis ini, peneliti diharuskan mendekati objek dengan pikiran polos tanpa asumsi, praduga, prasangka ataupun konsep. Pendekatan ini dalakukan untuk untuk mendeskripsikan penundaan pembayaran upah bagi pekerja di pabrik sandal UD. Nusantara. Namun dalam penelitian ini, peneliti hanya terfokus pada bagaimana penundaan pembayaran upah bagi pekerja di pabrik sandal UD. Nusantara desa Pasanggar kec. Pegantenan kab. Pamekasan.

\section{Penundaan Pembayaran Upah Pekerja di UD. Nusantara Pasanggar Pegantenan Pamekasan}

UD. Nusantara merupakan perusahaan yang bergerak dalam bidang produksi sandal yang mempekerjakan beberapa orang karyawan selaku pekerjanya. Dalam proses pengupahan, pengusaha memberi upah kepada para pekerjanya sesuai dengan kesepakatan yang telah disepakati oleh kedua belah pihak, dalam hal ini adalah pengusaha dan pekerja.

\footnotetext{
${ }^{12}$ Sukardi, Karyawan Pabrik Sandal UD. Nusantara Desa Pasanggar Pegantenan Pamekasan, Wawancara Langsung, (09 Desember 2017).
} 
Berbicara mengenai proses pengupahan, UD. Nusantara merupakan salah satu perusahaan yang gemar menyepelekan pembayaran upah para pekerjanya. Celakanya, penundaan pembayaran upah para pekerja tidak hanya dilakukan dalam jangka waktu yang singkat, melainkan dilakukan secara konsisten selama berbulan-bulan. Selama masa penundaan pembayaran atas upah sebagaimana dimaksud di atas, para pekerja pun giat mengingatkan pengusaha agar segera membayar upah yang belum terbayar. Penagihan yang dilakukan oleh pekerja inipun dilakukan secara konsisten setiap kali hendak menerima upah, hal ini dilakukan agar pihak pengusaha merasa terdesak dan dapat segera membayar upah para pekerja.

Pembayaran upah yang ditunda oleh pihak pengusaha sejatinya bukan tanpa alsan, pengeluaran perusahaan untuk membeli bahanbahan baru menjadi salah satu alasan tertundanya pembayaran upah bagi para pekerja. Berikut adalah pendapat yang dikemukakan oleh M. Walid sebagai pemilik perusahaan UD. Nusantara Pasanggar Pegantenan Pamekasan;

"Kalau menurut saya pribadi, penundaan upah itu boleh-boleh saja. Di mana hal itu dilakukan dengan alasan yang memang dibenarkan, seperti kalau di sini itu untuk beli bahan baru. Di sisi lain meskipun penundan itu dilakukan oleh seorang pengusaha, maka dalam beberapa waktu kedepan pasti diberikan juga sebagai bentuk perealisasian kewajibannya kepada para pekerja yang telah melakukan pekerjaannya".13

Berdasar penjelasan di atas, dapat diketahui bahwa pihak perusahaan memiliki kepentingan lain untuk memajukan perusahaan dengan mengorbankan pembayaran upah para pekerja yang tidak tepat pada waktunya. Sejatinya, hal ini tidak akan menuai masalah jika penundaan yang dilakukan belum keluar dari batas kewajarannya. Namun faktanya, penundaan pembayaran yang dilakukan oleh pihak UD. Nusantara dilakukan secara konsisten selama berbulan-bulan yang membangkitkan gejolak para pekerja untuk selalu melakukan penagihan setiap kali akan menerima upah demi mendapatkan haknya setelah melaksanakan kewajibannya.

Penundaan yang dilakukan oleh pihak pengusaha tidaklah membuat pekerja merasa senang, justru malah menjadi penyebab utama lahirnya kekecewaan dan rasa benci terhadap pengusaha serta kian mengurangi keihklasan para pekerja atas pekerjaan yang

${ }^{13}$ Walid, Pemilik UD. Nusantara Pasanggar Pegantenan Pamekasan, wawancara langsung, (20 Mei 2018). 
dilakukannya. Penundaan pembayaran upah pekerja yang dilakukan secara konsisten selama berbulan-bulan ini sudah layak dikatakan sebagai wujud kedzoliman pengusaha kepada para pekerjanya. Sebab dari pihak pengusaha terkesan menyepelekan pembayaran upah kepada para pekerja demi kepentingan perusahaan, hingga perbuatan ini merenggut hak dan kebutuhan hidup para pekerja setiap bulan.

Hal di atas senada dengan pernyataan Usman sebagai salah seorang pekerja di UD. Nusantara yang merupakan korban dari pembayaran upah yang tidak tepat waktu. Usman menuturkan bahwa;

"Menurut saya sah-sah saja ada penundaan pemberian upah, akan tetapi hal itu juga harus dilakukan dalam jangka waktu yang tidak lama, karena pekerja juga memiliki kebutuhan yang harus dipenuhi. Kalau ada penundaan yang sangat lama, maka menurut saya pengusaha telah melakukan kedzaliman kepada pekerjanya, dengan hanya memberikan pekerjaan tanpa memberikan upah yang dijanjikannya". ${ }^{14}$

Sistem borongan yang dimaksudkan oleh pekerja dan pengusaha di UD. Nusantara pada dasarnya menggunakan sistem upah per-unit hasil produksi yang dapat diselesaikan oleh para pekerja dan pekerja pun diperkenankan mengambil haknya langsung setelah pekerjaannya dilakukan dengan sempurna. Adapun besaran upahnya adalah sesuai dengan kesepakatan antara pengusaha dan pekerja.

Berkaitan dengan besarnya upah di UD. Nusantara didasarkan pada jumlah garapan, ukuran sandal yang digarap, model sandal yang digarap dan bahan sandal yang digunakan dalam membuat sandal itu sendiri. Sistem yang digunakan dalam pengupahan tersebut adalah sistem hasil, yakni besar upah didasarkan pada banyaknya hasil produksi yang telah diselesaikan oleh pekerja.

\section{Pandangan Hukum Islam Terhadap Penundaan Pembayaran Upah Pekerja di UD. Nusantara Pasanggar Pegantenan Pamekasan \\ Istilah upah-mengupah dalam hukum Islam dikenal dengan sebutan akad ijarah, yakni sewa menyewa jasa atau barang antara penyewa dengan pemberi sewa. Ijarah itu sendiri merupakan}

\footnotetext{
${ }^{14}$ Usman, Pekerja di UD. Nusantara Pasanggar Pegantenan Pamekasan, wawancara langsung (20 Mei 2018).
} 
pemilikan jasa dari seorang 'ajir (orang yang kontrak tenaganya) oleh seorang musta'jir (orang yang mengontrak tenaga), serta pemilikan harta dari pihak musta'jir oleh seorang 'ajir. Ijarah itu sendiri disertai kompensasi. Di mana akad tersebut adakalanya dengan menyebutkan jasa pekerjaan itu sendiri. Apabila transaksi tersebut menyebutkan jasa pekerjaan rertentu, maka yang disepakati itulah yang merupakan jasa yang harus dilaksanakan. ${ }^{15}$

Jika dikaitkan dengan praktik pengupahan yang terjadi di UD. Nusantara Pasanggar Pegantenan Pamekasan, maka dalam hal itu dapat dikategorikan sebagai upah pengupah yang menyebutkan pekerjaan yang harus dilakukan oleh orang yang disewa jasanya. Sebagaimana dalam temuan penelitian dijelaskan bahwa pada dasarnya pekerja di UD. Nusantara Pasanggar Pegantenan Pameksan pada saat akan bekerja diberikan instruksi sebelumnya oleh pengusaha terkait dengan apa yang harus digarapnya.

Di sisi lain dalam melakukan akad ijarah itu sendiri, terdapat beberapa rukun dan syarat ijarah yang harus dipenuhi untuk menentukan sah tidaknya akad yang dilakukan. Di mana rukun dari ijarah diantaranya adalah orang yang berakad, upah, manfaat dan shighat. 16

Sedangkan praktik upah-mengupah yang ada di UD. Nusantara sudah memenuhi rukun ijarah itu sendiri. Di mana orang yang berakad adalah pekerja dan pengusaha, upahnya berupa gaji, manfaatnya berupa jasa pembuatan sandal dan shighat yang terjadi antara pekerja dan pengusaha. Adapun berkaitan dengan syarat ijarah dalam praktik upah mengupah di UD. Nusantara juga sudah terpenuhi mulai dari syarat terjadinya akad, syarat sah ijarah dan syarat-syarat lainnya. Oleh karena itu, secara rukun dan syarat dapat dipastikan bahwa akad ijarah atau upah mengupah yang dilakukan oleh pekerja dengan UD. Nusantara merupakan akad yang sah menurut hukum Islam. Hal itu dikarenakan akad yang sah itu sendiri merupakan akad yang memenuhi rukun dan syarat dari akad yang dilakukannya tersebut. ${ }^{17}$

Di sisi lain terkait dengan pengupahan yang ada di UD. Nusantara sebagaimana dijelaskan dalam temuan penelitian ini bahwa upah kerja boleh diambil langsung oleh pekerja setelah melakukan pekerjaannya. Dalam hukum Islam, sistem yang

\footnotetext{
${ }^{15}$ Taqyuddin An Nabhani, Membangun Sistem Alternatif Islam (Surabaya: Risalah Gusti, 2009),. 83.

${ }^{16}$ Abd Hadi, Dasar Dasar Hukum Ekonomi Islam,. 197-198.

${ }^{17}$ Pasal 28 ayat (1) Kompilasi Hukum Ekonomi Syariah
} 
demikian sangatlah bagus dan sangat dianjurkan bagi setiap pengusaha. Di mana Islam menganjurkan bagi setiap pengusaha untuk segera membayar upah pekerjanya. Hal ini sebagaimana hadits Rasulullah SAW. :

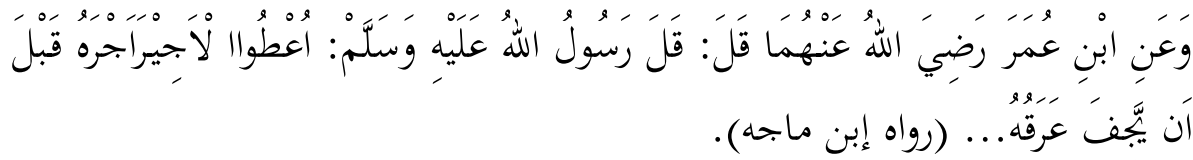

"Dari Ibnu Umar RA. Ia berkata "Rasullah Saw. Bersabda:" Berilah kepada pekerja upahnya sebelum keringatnya kering"( HR. Ibnu Majah). ${ }^{18}$

Hadits di atas menjelaskan tentang perintah disegerakannya pemberian upah kepada setiap pekerja. Di mana sistem pembayaran mengembangkan struktur pembayaran dan sistem yang layak, adil dan transparan. Pembayaran untuk kontribusi mengkaitkan imbalan dengan usaha, hasil, kecakapan dan keterampilan. ${ }^{19}$ Oleh karena itut, memang sepantasnya para pengusaha dalam mempekerjakan orang lain dalam menjalankan usahanya perlu untuk menyegerakan pemberian upahnya agar akad yang dilakukan benar-benar diridloi oleh Allah Taala.

Kemudian temuan selanjutnya yang ditemukan oleh peneliti dalam penelitian ini adalah bahwa besar upah didasarkan banyaknya hasil yang telah digarap oleh pekerja dalam memproduksi sandal. Di mana hal tersebut jika dikaji dalam hukum Islam, dapat disimpulkan bahwa hal tersebut merupakan perbuatan yang tidak bertentangan dengan hukum Islam. Di mana dalam hukum Islam memang dalam penentuan upah penyewaan jasa yang digunakan oleh seseorang boleh didasarkan waktu, kesulitan kerja. Sebagaimana dalam DSNMUI No. 09/DSN-MUI/IV/2000 ketentuan kedua bagian (9) ditentukan bahwa Kelenturan (flexibility) dalam menentukan sewa atau upah dapat diwujudkan dalam ukuran waktu, tempat dan jarak.20

Selain itu, pembahasan selanjutnya adalah tentang permasalahan utama yang menjadi pokok masalah dalam penelitian ini. Sebagaimana telah disebutkan dalam temuan selanjutnya dalam penelitian ini bahwa sering kali pengusaha di UD. Nusantara menunda-nunda pembayaran upah pekerjanya. Dalam Islam pada

\footnotetext{
${ }^{18}$ Ibnu Majah, Sunan Ibnu Majah, dalam Ensiklopedia Hadits 4 Sunan Ibnu Majah, ed. Muhammad Ghazali, et. Al. (Jakarta: Almahira, 2013),. 441.

${ }^{19}$ Sedarmayanti, Manajemen Sumber Daya Manusia,. 19.

${ }^{20}$ DSN-MUI Nomor 09/DSN-MUI/IV/2000.
} 
dasanya menunda upah boleh-boleh saja dilakukan oleh pengusaha selama para pekerjanya menyepakati dan rela dengan adanya penundan tersebut. Hal ini dapat didasarkan pada kesepakatan keduanya, yang dalam Islam diperbolehkan melakukan kesepakatan tersebut selama tidak bertentangan dengan hukum Islam.

Namun tentunya penundaan yang dilakukan oleh pengusaha tidaklah berturut-turut. Sebagaimana temuan lainnya yang disebutkan oleh peneliti bahwa penundaan dilakukan secara berulang-ulang dan pekerja secara berulang-ulang pula dalam melakukan penagiha atas haknya. Maka dari adanya praktik yang demikian, tentu bertentangan dengan prinsip pengupahan dalam Islam. Di mana pada dasarnya Islam menganjurkan untuk selalu menyegerakan pembayaran upah pekerja dalam perusahaannya. Terlebih lagi penundaan yang dilakukan pengusaha tidak hanya sementara, melainkan berbulan-bulan yang membuat pekerja sakit hati dan tidak ikhlas.

Di sisi lain hal tersebut juga bertentangan dengan ketentuan Allah, bahwa Allah SWT. dalam firman-Nya menyerukan untuk menyegerakan pembayaran upah bagi setiap pekerja. Hal ini sebagaimana tertera dalam salah satu firman-Nya dalam surah alThalaq ayat 6, bahwa Allah berfirman mengenai anak yang disusukan oleh istri yang telah diceraikan:

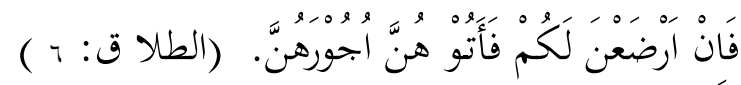

"Jika mereka telah menyusukan (anak-anak)mu untukmu, maka berikanlah kepada mereka upahnya". (Al-Thalaq: 6). ${ }^{21}$

Ayat di atas memerintahkan untuk memberikan upah itu secepatnya setelah selesainya pekerjaan. Huruf "fa" pada kalimat "Fa'tu ujūrahunna" untuk tartib dan ta'qīb. Makna tartib: bahwa yang kedua setelah yang pertama. Makna ta'qib adalah yang kedua terjadi segera setelah yang pertama tanpa jeda. ${ }^{22}$

Selain itu, dalam temuan lainnya dinyatakan bahwa pekerja telah mengingatkan pengusaha atas upah yang belum dibayar sebagai hutangnya dengan cara memintanya berkali-kali sampai upah yang ditunda terbayarkan. Maka dari dalam praktik yang demikian terdapat kedzaliman yang dilakukan oleh pengusaha pada

\footnotetext{
${ }^{21}$ Departemen Agama, Al-Qur'an Dan Terjemahannya (Bandung: CV. Penerbit JArt, 2005),. 560.

${ }^{22}$ Fuad Riyadi, "Sistem dan Strategi Pengupahan Perspektif Islam", Iqtishadia, 1 (Maret, 2015),. 178.
} 
pekerjanya, di mana pengusaha hanya mengambil jasanya tanpa ada upah yang diberikan dengan segera.

Bahkan pendapat salah satu ulama' bernama al-Munawi menyatakan bahwa: "Diharamkan menunda pemberian gaji padahal mampu menunaikannya tepat waktu. Adapun yang dimaksud memberikan gaji sebelum keringat si pekerja kering adalah ungkapan untuk menunjukkan diperintahkannya memberikan gaji setelah pekerjaan itu selesai ketika si pekerja meminta walau keringatnya tidak kering atau keringatnya telah kering. " 23

Bahkan Allah SWT. memberi ancaman yang sangat mengerikan bagi pengusaha yang menunda-nunda upah pekerjanya. Sebagaimana Rasulullah SAW. bersabda dalam haditsnya diriwayatkan oleh Imam Bukhori dari Abu Hurairah, Beliau bersabda: Allah SWT. berfirman:

"Tiga jenis (manusia) yang Aku akan menjadi musuhnya kelak di hari kiamat, yaitu seseorang yang memberi dengan nama-Ku kemudian berkhianat, seseorang yan menjual orang yang merdeka yang kemudian memakan uangnya, dan seseorang yang mempekerjakan pekerja dan telah diselesaikan pekerjaannya tetapi ia tidak memeberikan upahnya". (H. R. Bukhori). ${ }^{24}$

Dari penjelasan hadits di atas dapat dikatakan bahwa orang yang tidak memberikan upah pekerjanya setelah menyelesaikan pekerjaannya akan menjadi musuh Allah kelak di neraka. Oleh karena itu hal ini merupakan sesuatu yang tidak seharusnya dilakukan oleh seorang pengusaha, di mana perbuatan yang demikian adalah suatu kedzaliman yang akan diberikan balasan yang sangat dahsyat oleh Allah SWT. Karena sesungguhnya upah merupakan kewajiban yang harus dibayarkan oleh pengusaha kepada pekerjanya, yang hukumnya sama dengan hutang.

Prinsip pengupahan dalam hukum Islam tidak menghendaki majikan yang suka mengingkari waktu pembayaran upah yang telah disepakati. Jika ditunda, hal itu menjadi hutang majikan kepada pekerja sebesar jumlah upah yang ditunda tersebut. Setelah pekerja melunasi pekerjaannya, majikan haruslah menepati janjinya. Demikian pula dengan perjanjian yang dibuat dan telah disepakati

\footnotetext{
${ }^{23}$ Fuad Riyadi, "Sistem dan Strategi Pengupahan Perspektif Islam,. 178.

${ }^{24}$ Abu Abdillah Muhammad bin Ismail al-Bukhori, Shohih Bukhori 2, dalam Ensiklopedia 2 Shahih Bukhori 2, ed. Subhan Abdullah, et. Al, (Jakarta: Almahira, 2012),. 150.
} 
oleh kedua belah pihak antara pihak pekerja dan pihak pengusaha yang dalam hal ini adalah UD. Nusantara. Adanya perjanjian sebagaimana dimaksud di atas harusnya menjadi pengikat sekaligus pedoman bagi pengusaha agar tidak selalu menunda pembayaran upah bagi para pekerjanya.

Berdasarkan uraian di atas, maka dapat ditarik benang merah bahwa proses pembayaran upah yang dilakukan oleh UD. Nusantara kepada para pekerjanya tidak sesuai dengan prinsip pengupahan dalam hukum Islam dan merupakan perbuatan yang dilarang dalam Islam. Sebab penundaan yang dilakukan oleh UD. Nusantara dalam membayar upah para pekerjanya dilakukan secara konsisten yang akhirnya mendorong pekerja untuk selalu melakukan penagihan kepada pengusaha. Hal ini menunjukkan bahwa selain bertentangan dengan Hukum Islam, penundaan pembayaran yang dilakukan oleh UD. Nusantara juga bertentangan dengan akad yang telah disepekati sebelumnya antara pekerja dan pengusaha, sehingga pihak pekerja merasa terdzolimi akibat upah yang belum dibayarkan oleh pihak pengusaha.

\section{Penutup}

Berdasarkan hasil uraian di atas, maka dapat disimpulkan halhal sebagai berikut:

1. Penundaan upah di UD. Nusantara memang pernah dilakukan oleh pengusaha kepada para pekerjanya, di mana hal itu dilakukan terkadang dalam jangka waktu yang lama dan bahkan dibutuhkan kesabaran dan kegigihan untuk meminta langsung kepada pengusaha secara berulang-ulang oleh pekerja demi mendapatkan hak pekerja berupa upah yang selalu ditunda.

2. Pandangan Hukum Islam terhadap penundaan pembayaran upah di UD. Nusantara adalah bahwa sistem yang digunakan merupakan sistem yang sesuai dengan hukum Islam, akan tetapi penundaan yang terjadi di dalamnya merupakan perkara yang tidak diperkenankan karena bertentangan dengan hukum Islam, yakni bertentangan dengan akad yang telah disepakati antara kedua belah pihak. Selain itu, terdapat pula unsur kedzaliman di dalamnya, yakni adanya penundaan yang terjadi selama berbulan-bulan hingga memaksa para pekerja untuk selalu melakukan penagihan demi mendapatkan haknya. 


\section{Daftar Pustaka}

Al-Hasani Jaribah, Fikih Ekonomi Umar Bin Al-Khothab. Jakarta: Pustaka Al-Kaustsar Grup, t. th.

An NabhaniTaqyuddin, Membangun Sistem Alternatif Islam. Surabaya: Risalah Gusti, 2009.

Arikunto Suharsimi, Proses Penelitian Suatu Pendekatan praktik. Jakarta: Rineka Cipta, 2013.

Ascarya. Akad Dan Produk Bank Syariah, Jakarta: PT. Raja Grafindo Persada, 2008.

Asyhadie, Zaeni. Hukum Perusahaan Dan Kepailitan, Jakarta: PT Gelora aksara pratama,2012.

Bukhori, Abu Abdillah Muhammad bin Ismailal. Shohih Bukhori 2. dalamEnsiklopedia 2 al-Kutub al-Sittah Shahih Bukhori $2 . \quad$ ed. Subhan Abdullah, et. Al. Jakarta: Almahira, 2012.

Departemen Agama ,Al-Qur'an Dan Terjemahannya, Bandung: CV. Penerbit J-Art, 2005.

Hadi Abd, Dasar Dasar Hukum Ekonomi Islam, Surabaya: Putra Media Nusantara, 2010.

Hakim Lukman, Prinsip-Prinsip Ekonomi Islam, Surakarta: Pt. Gelora Aksara Pratama, 2012.

Hasibuan Malayu S. P. , Manajemen Sumber Daya Manusia, Jakarta :PT Bumi Aksara,2015.

Suhendi, Hendi. Fiqih Muamalah, Jakarta: PT Raja Grafinda Perseda, 2010

Moleong Lexy J. , Metodologi Penelitian Kulitatif Edisi Revisi. Bandung: Remaja Rosda Karya, 2014.

Muslim. al-Kutub al-Sittah : Shahih Muslim 2. dalamEnsiklopedia Hadits 4 Shahih Muslim . ed. Masyhari. et. Al. Jakarta: Almahira, 2012.

Majah, Ibnu. Sunan Ibnu Majah, dalam Ensiklopedia Hadits 4 Sunan Ibnu Majah. ed. Muhammad Ghazali. et. Al. Jakarta: Almahira, 2013.

Moleong Lexy J. , Metodologi Penelitian Kulitatif. Bandung: Remaja Rosda Karya, 2005.

Muslich, Ahmad Wardi. Figh Muamalah. Jakarta: Amzah, 2015.

Riyadi, Fuad. "Sistem dan Strategi Pengupahan Perspektif Islam". Iqtishadia. 1. Maret, 2015. 
Sarwat, Ahmad. Seri Fiqih Kehidupan (7) : Muamalat. Jakarta: DU Publishing, t. th.

Setiawan, Firman "Al-ijarah Al-A'mal Al-Mustarakah Dalam Perspektif Hukum Islam Studi Kasus Urunan Buruh Tani Tembakau di Desa Totosan Kecamatan Batang-batang Kabupaten Sumenep Madura)". Dinar. 2. Januari, 2015.

Sedarmayanti,Manajemen Sumber Daya Manusia, Reformasi Birokrasi, Dan Manajemen Negeri Sipil ,Bandung:PT Refika Aditama ,2007.

Setiawan Andy Widjaya, Selamatkan Bisnis Anda Tumpas 101 Penyakit Bisnis, Jakarta: Literindo, 2014.

Sugiyono, Metode penelitian Kuantitatif Kualitatif dan RED, Bandung: Alfabeta, 2011.

Sukirno Sadono, Mikroekonomi Teori Pengantar, Jakarta: Raja Wali Pers, 2010.

Suwandi dan Basrowi ,Memahami Penelitian Kualitatif, Jakarta: Rineka Cipta, 2008.

Syam Zukhairil Hadi, Pengupahan Karyawan Dalam Perspektif Fiqih Muamalah (Studi Kasus Pada Home Industry Konveksi Di Pulo Kalibata Jakarta Selatan, Skripsi Uin Syarif Hidayatullah, Jakarta, 2011.

Tim Penyusun, Pedoman Karya Ilmiah, Pamekasan: Sekolah Tinggi Agama Islam Negeri Pamekasan, 2015.

Yuliati, Sistem Pembayaran Upah Pekerja Perkebunan Kelapa Sawit PT. Sumur Pandanwangi Diseruyan (Di Tinjau Dari Undang-Undang Ketenagakerjaan Dan Ekonomi Islam, (Skripsi IAIN Palangka Raya, 2017).

Yusuf Ahmad Muhammad, ensiklopedi tematis ayat al-quran dan hadits, Jakarta: widya cahaya, 2009.

Zuhayly, Wahbah. al-Figh al-Islami wa Adillatuhu. vol. 8. Damaskus: Dar al-Fikr, 1985.

Monografi Desa Pasanggar Tahun 2016.

http://rianamuslikhah. blogspot. co. id/2015/02/makalah-upahdalam-islam? $\mathrm{m}=1$ 